\title{
Diversity and molecular characterization of novel hemoplasmas infecting wild rodents from different Brazilian biomes
}

\author{
Luiz Ricardo Gonçalves ${ }^{\mathrm{a}, \mathrm{b}}$, André Luiz Rodrigues Roque ${ }^{\mathrm{c}}$, Carlos Antonio Matos ${ }^{\mathrm{b}, \mathrm{d}}$, \\ Simone de Jesus Fernandes ${ }^{\mathrm{b}}$, Isabella Delamain Fernandez Olmos ${ }^{\mathrm{b}}$, \\ Rosangela Zacarias Machado ${ }^{\mathrm{b}}$, Marcos Rogério André ${ }^{\mathrm{b}, *}$ \\ a Pós-graduação em Microbiologia Agropecuária, Universidade Estadual Paulista (FCAV/UNESP), Jaboticabal, SP, Brazil \\ ${ }^{\mathrm{b}}$ Laboratório de Imunoparasitologia, Departamento de Patologia Veterinária, Faculdade de Ciências Agrárias e Veterinárias/Universidade Estadual Paulista \\ (FCAV/UNESP), Jaboticabal, SP, Brazil \\ ${ }^{c}$ Laboratório de Biologia de Tripanosomatídeos, Fundação Oswaldo Cruz/FioCruz, Rio de Janeiro, RJ, Brazil \\ d Direcção de Ciências Animais, Maputo, Moçambique
}

\section{A R T I C L E I N F O}

\section{Article history:}

Received 20 July 2015

Received in revised form 9 October 2015

Accepted 22 October 2015

\section{Keywords:}

Hemotropic mycoplasmas

Wild rodents

Molecular characterization

Brazil

\begin{abstract}
A B S T R A C T
Although hemoplasma infection in domestic animals has been well documented, little is known about the prevalence and genetic diversity of these bacteria in wild rodents. The present work aimed to investigate the occurrence of hemotrophic mycoplasmas in wild rodents from five Brazilian biomes, assessing the $16 \mathrm{~S}$ rRNA phylogenetic position of hemoplasma species by molecular approach. Spleen tissues were obtained from 500 rodents, comprising 52 different rodent species trapped between 2000 and 2011. DNA samples were submitted to previously described PCR protocols for amplifying Mycoplasma spp. based on 16S rRNA, followed by sequencing and phylogenetic inferences. Among 457 rodent spleen samples showing absence of inhibitors, 100 (21.9\%) were PCR positive to Mycoplasma spp. The occurrence of hemotropic mycoplasmas among all sampled rodents was demonstrated in all five biomes and ranged from 9.3\% (7/75) to $26.2 \%(38 / 145)$. The Blastn analysis showed that amplified sequences had a percentage of identity ranging from 86 to $99 \%$ with other murine hemoplasmas. The ML phylogenetic analysis of $16 \mathrm{~S}$ rRNA gene of 24 positive randomly selected samples showed the presence of ten distinct groups, all clustering within the Mycoplasma haemofelis. The phylogenetic assessment suggests the circulation of novel hemoplasma species in rodents from different biomes in Brazil.
\end{abstract}

(C) 2015 Elsevier Ltd. All rights reserved.

\section{Introduction}

Hemotropic mycoplasmas are epicellular erythrocytic bacteria attach to red blood cells of a wide variety of wild and domestic animals, including humans. Although hemoplasma infection in domestic animals has been well documented, little is known about the prevalence, genetic diversity, and routes of transmission, interactions among bacteria-host-vectors, and the impact of infection on wild animal's health [1-3]. Blood-sucking arthropods (ticks, fleas and lice) are responsible for the transmission of hemotropic mycoplasmas among animals [4,5].

Phylogenetic analyses have identified two major clusters of hemoplasmas, comprising Mycoplasma suis and Mycoplasma haemofelis groups. Several hemoplasma species infecting wild and domestic animals were included in these two clusters [6,7].

\footnotetext{
* Corresponding author. Tel.: +55 163209 7302; fax: +55 1632024275.

E-mail address: marcos_andre@fcav.unesp.br (M.R. André).
}

Phylogenetic approaches have been showing the circulation of a wide and diverse number of genotypes and/or Candidatus to new hemoplasma species in wild animals, including some with zoonotic potential $[8,9]$.

Rodentia is the most diversified and widespread order of mammals. A wide number of species is found in different habitats, including semi-aquatic, terrestrial and semi-fossorial ones in Brazil [10]. Rodent species may act as reservoirs for diverse zoonotic pathogens [11-13]. However, the zoonotic potential of rodent hemoplasmas has not yet been established [14].

Recently, Mycoplasma haemomuris, one of two haemotropic species of the Mycoplasma genus currently recognized in rodents, has ben separated in two subgroups genetically distinct: 'Candidatus M. haemomuris subsp. musculi', detected in small Japanese field mouse (Apodemus argenteus) an endemic species from Japan [15] and 'Candidatus M. haemomuris subsp. ratti', detected in Rattus rattus [16]. According to the authors, the separation of $M$. haemomuris in two species depends mostly on the host species where these strains have been detected rather than the geographical 
localization where positive animals have been sampled. Experimental and/or field studies have incriminated lice (Polyplax serrata and $P$. spinulosa) as vectors of $M$. coccoides and $M$. haemomuris among rodents [14,17].

Considering the large number of hemotropic mycoplasma species, the crescent number of Candidatus to new species recently described in different species of mammals and the wide spectrum of rodents distributed around the world, the diversity of hemoplasmas infecting rodents are presumably more complex than is currently supposed.

Regarding the occurrence of hemotropic mycoplasmas in rodents in Brazil, novel hemoplasmas have been reported in capybaras in the state of Paraná [18]. Besides, hemoplasmas have been detected in several other wild animals in Brazil, including wild carnivores [19], cervids [20] and non-human primates [21,22].

The present study aimed to investigate the occurrence and assessment of the 16S rRNA phylogenetic position of hemoplasma species infecting wild rodents from different Brazilian biomes through molecular approach.

\section{Material and methods}

\subsection{Distribution and rodent species sampled}

Between 2000 and 2009, different rodent species (52) were trapped in five Brazilian biomes (Fig. 1) (http://www. informativoflorestal.com.br). Animals were caught using Tomahawk and Shermann "live-traps" during previous studies performed by the Laboratories of Trypanosomatid Biology and of Biology and Parasitology of Wild Mammals Reservoirs Laboratories, Oswaldo Cruz Institute, Rio de Janeiro, Brazil [23-25]. Euthanasia of animals was performed for taxonomic identification and/or diagnosis of parasites. Rodents were chemically immobilized using an association of ketamine hydrochloride $(100 \mathrm{mg} / \mathrm{mL})$ and acepromazine $(10 \mathrm{mg} / \mathrm{mL})$ intramuscularly. When the death of anesthetized animal did not occur after total blood collection, then euthanasia was performed through the application of Potassium Chloride $19.1 \%$ via intracardiac $(2 \mathrm{~mL} / \mathrm{kg})$.

Spleen tissues from 500 rodents were collected and stored in DNase and RNase-free microtubes, containing ethanol and stored at $-20^{\circ} \mathrm{C}$ until DNA extraction. Sampling procedures were approved by Brazilian Institute for the Environment and the Natural Renewable Resources (IBAMA), (IBAMA/CGFAU/LIC 3665-1) and Oswaldo Cruz Foundation (FIOCRUZ) ethics committee (P0007-99; P017903; P0292/06; L0015-07).

\subsection{PCR assays}

DNA was extracted from $10 \mathrm{mg}$ of each rodent spleen tissue using the DNeasy ${ }^{\circledR}$ Blood \& Tissue Kit (Qiagen ${ }^{\circledR}$, Valencia, California, USA), according to manufacturer's instructions. DNA concentration and absorbance ratio (260/280) nm were measured using a spectrophotometer (Nanodrop, Thermo Scientific, USA). Microtubes containing ultra-pure sterile water were intercalated between each series of twenty rodent spleen samples and submitted to DNA extraction.

In order to discard the presence of PCR inhibitors, each sample of spleen extracted DNA was used as a template in an internal control PCR targeting the mammal IRBP gene ("Interphotoreceptor Retinoid Binding Protein") as previously described [26]. Negative samples to IRBP gene-PCR were subsequently submitted to another internal control PCR targeting the GAPDH gene as previously described [27]. Positive samples to above described internal

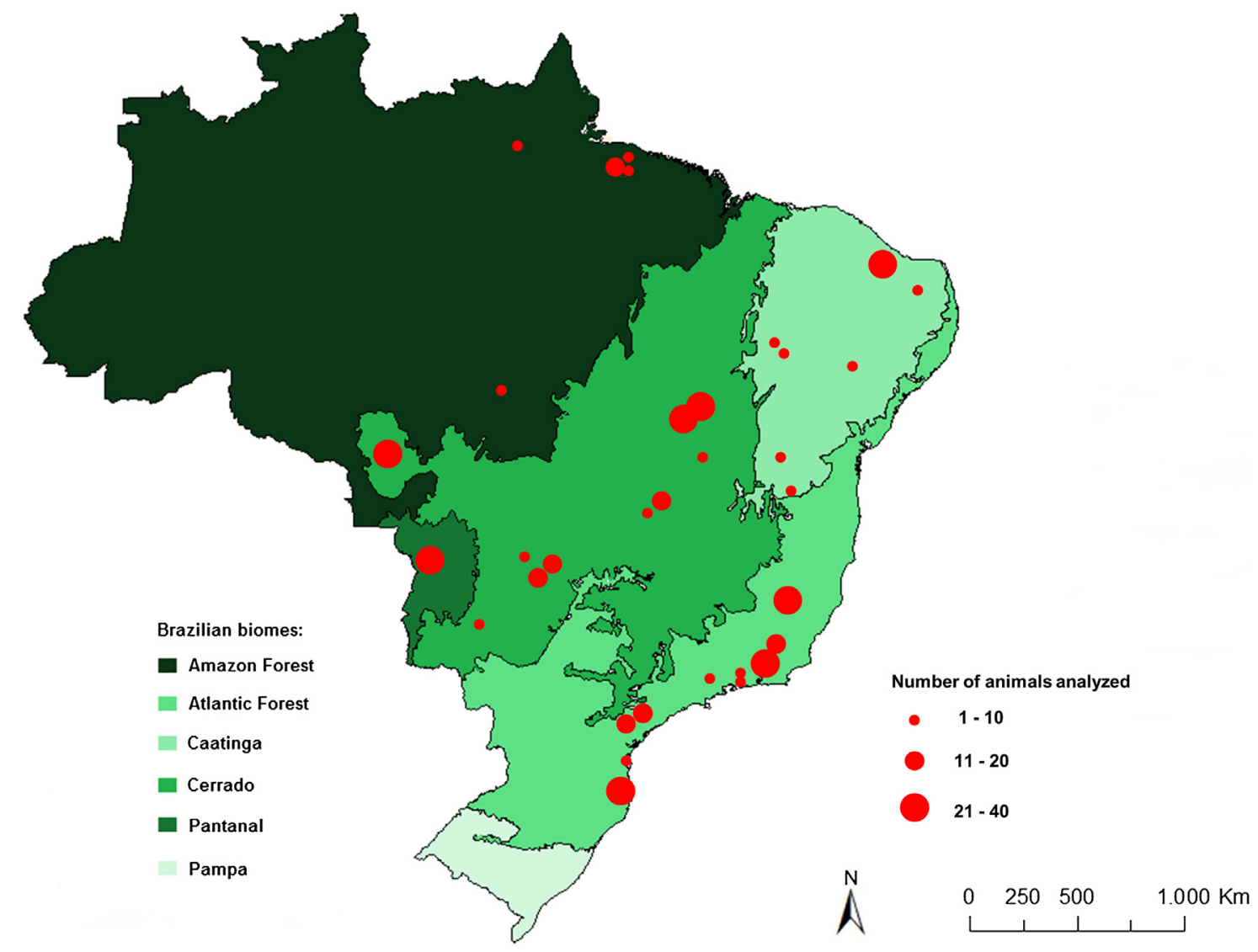

Fig. 1. Distribution of rodents sampled in different Brazilian biomes. 
control PCR protocols were subsequently submitted to PCR assays targeting 16S rRNA-Mycoplasma spp.

Previously described PCR protocols based on 16S rRNA were utilized to amplify Mycoplasma spp. DNA, using two sets of primers, namely HemMycop16S-41s (5'-GYATGCMTAAYACATGCAAGTCGARCG-3') and HemMyco16S-938as (5'-CTCCACCACTTGTTCAGGTCCCCGTC-3') (fragment of $\sim 800 \mathrm{bp}$ ), and HemMycop 16S-322s (5'-GCCCATATTCCTACGGGAAGCAGCAGT-3') and HemMycop16S-1420as (5'-GTTTGACGGGCGGTGTGTACAAGACC$3^{\prime}$ ) (fragment of $\sim 800 \mathrm{bp}$ ) as previously described [8]. $M$. haemofelis DNA obtained from a naturally infected cat [28] was used as positive control. Ultra-pure sterile water was used as negative control in all PCR assays described above. The 16S rRNA Mycoplasma spp.-positive samples were additionally submitted to RNaseP gene-Mycoplasma sp. (165 bp) PCR assay using the oligonucleotides HemoMyco RNaseP30s (5'GATKGTGYGAGYATATAAAAAATAAARCTCRAC- $3^{\prime}$ ) and HemoMyco RNaseP200as (5'-GMGGRGTTTACCGCGTTTCAC-3') as previously described [8].

\subsection{Statistical analysis}

The Pearson's Chi-squared test was used to evaluate the association between biomes and the number of rodents positive for hemoplasmas using the SAS program (Statistical Analysis System version 9.2). Significance was defined as $p<0.05$.

\subsection{Phylogenetic analysis}

PCR products of the expected size for each assay were purified from the gel using Silica Bead DNA Gel Extraction Kit (Fermentas, São Paulo, SP, Brazil). Amplicons were sequenced in both directions using the same PCR primers (forward and reverse) by Sanger sequencing at (ABI Prism 310 Genetic Analyser-Applied Byosystem/Perkin Elmer). Consensus sequences were obtained through the analysis of the sense and antisense sequences using the CAP3 program (http://mobyle.pasteur.fr/cgi-bin/MobylePortal/ portal.py). Comparisons with sequences deposited in GenBank were done using the basic local alignment search tool (BLASTn) [29]. The sequences were aligned with sequences published in GenBank using Clustal/W [30] and manually adjusted in Bioedit v. 7.0.5.3 [31]. Phylogenetic inference based on maximum likelihood criterion (ML), was inferred with RAxML-HPC BlackBox 7.6.3 [32] through the CIPRES Science Gateway [33]. Akaike information criterion was used in Mega 5.05 to identify the most appropriate model of nucleotide substitution. GTRGAMMA + I model was chosen as the most appropriate for the Maximum Likelihood analysis of the $16 \mathrm{~S}$ rDNA alignment.

\section{Results}

\subsection{Detection of hemoplasmas}

Out of 500 rodent spleen samples analyzed, 457 were positive to internal control (IRBP gene) PCR. All negative samples to IRBP gene-PCR were also negative to GAPDH gene PCR and were excluded from subsequent analysis. Among 457 rodent spleen samples analyzed, 100 (21.9\%) were PCR positive to Mycoplasma spp. (Table 1). The occurrence of hemotropic mycoplasmas among sampled rodents in each one of the five different biomes was of 9.3\% (7/75) in the Caatinga, 12.5\% (4/32) in the Pantanal, 24.7\% $(43 / 174)$ in the Cerrado, $25.8 \%(8 / 31)$ in the Amazon Forest and 26.2\% (38/145) in Atlantic Forest biome. The statistical analysis showed that occurrence of hemoplasma is influenced by different biomes $\left(\chi^{2}=11.24, p=0.024\right)$. Statistical difference was observed
Table 1

Number and distribution of rodent species positive to Mycoplasma spp.

\begin{tabular}{|c|c|c|c|}
\hline Biome/state & Species & $\begin{array}{l}\text { No. of } \\
\text { positive } \\
\text { rodents to } \\
\text { internal } \\
\text { control (IRBP } \\
\text { gene) }\end{array}$ & $\begin{array}{l}\text { No. of } \\
\text { positive } \\
\text { rodents to } \\
\text { Mycoplasmo } \\
\text { spp. (16S } \\
\text { rRNA) }\end{array}$ \\
\hline
\end{tabular}

\begin{tabular}{|c|c|c|}
\hline \multicolumn{3}{|l|}{ Atlantic forest } \\
\hline \multirow[t]{14}{*}{ Rio de Janeiro } & Akodon sp. & 27 \\
\hline & Necromys lasiurus & 4 \\
\hline & Brucepattersonius sp. & 1 \\
\hline & Delomys dorsalis & 9 \\
\hline & Euryoryzomys russatus & 2 \\
\hline & Oligoryzomys nigripes & 4 \\
\hline & Oligoryzomys sp. & 1 \\
\hline & Oxymycterus dasythricus & 3 \\
\hline & Oxymycterus sp. & 3 \\
\hline & Trinomys dimidiatus & 1 \\
\hline & Trinomys iheringi & 3 \\
\hline & Sciurus sp. & 1 \\
\hline & Sphiggurus sp. & 1 \\
\hline & Sphiggurus villosus & 1 \\
\hline \multirow[t]{4}{*}{ Minas Gerais } & Nectomys squamipes & 4 \\
\hline & Thrichomys apereoides & 10 \\
\hline & Oligoryzomys nigripes & 7 \\
\hline & Calomys cerqueirae & 3 \\
\hline \multirow[t]{6}{*}{ São Paulo } & Oligoryzomys sp. & 4 \\
\hline & Oligoryzomys nigripes & 11 \\
\hline & Oligoryzomys flavescens & 3 \\
\hline & Akodon montensis & 11 \\
\hline & Calomys tener & 10 \\
\hline & Mus musculus & 2 \\
\hline \multirow[t]{5}{*}{ Santa Catarina } & Akodon montensis & 5 \\
\hline & Mus musculus & 1 \\
\hline & Euryoryzomys russatus & 10 \\
\hline & Sooretamys angouya & 2 \\
\hline & Mus musculus & 1 \\
\hline
\end{tabular}

Amazon forest

Pará

Rattus rattus

Mus musculus

Proechimys goeldii

Proechimys roberti

Proechimys gr.cuvieri

Proechimys sp.

Zygodontomys sp.

Mato Grosso

Rattus rattus

Proechimys sp.

Necromys lasiurus

Caatinga

Bahia

Necromys lasiurus

Mus musculus

Thrichomys inermis

Thrichomys laurentius

Thrichomys sp.

Galea spixii

Galea spixii

Mus musculus

Rattus rattus

Thrichomys laurentius

Rhipidomys macrurus

Thrichomys laurentius

$\begin{array}{ll}\text { Rio Grande do } & \text { Cavia sp. } \\ \text { Norte } & \text { Thrichomys sp. }\end{array}$

Cerrado

Mato Grosso

Rattus rattus Necromys lasiurus

Calomys sp.

Mato Grosso do Calomys expulsus

Sul

Necromys lasiurus

Nectomys rattus

Nectomys sp.

Nectomys squamipes

Goiás

5
3
-
-
-
-


Table 1 (Continued)

\begin{tabular}{|c|c|c|c|}
\hline Biome/state & Species & $\begin{array}{l}\text { No. of } \\
\text { positive } \\
\text { rodents to } \\
\text { internal } \\
\text { control (IRBP } \\
\text { gene) }\end{array}$ & $\begin{array}{l}\text { No. of } \\
\text { positive } \\
\text { rodents to } \\
\text { Mycoplasma } \\
\text { spp. (16S } \\
\text { rRNA) }\end{array}$ \\
\hline \multirow{20}{*}{ Tocantins } & Hylaeamys megacephalus & 7 & - \\
\hline & Necromys lasiurus & 6 & 1 \\
\hline & Nectomys rattus & 5 & 2 \\
\hline & Nectomys sp. & 2 & 1 \\
\hline & Oecomys gr. bicolor & 4 & - \\
\hline & Oryzomys megacephalus & 2 & - \\
\hline & Rattus rattus & 4 & 1 \\
\hline & Rhipidomys sp. & 10 & 5 \\
\hline & Oligoryzomys nigripes & 2 & - \\
\hline & Oligoryzomys fornesi & 2 & 1 \\
\hline & Calomys sp. & 27 & 4 \\
\hline & Hylaeamys sp. & 9 & 3 \\
\hline & Necromys lasiurus & 9 & 6 \\
\hline & Rhipidomys sp. & 5 & 2 \\
\hline & Mus musculus & 1 & 1 \\
\hline & Juliomys sp. & 1 & - \\
\hline & Oligoryzomys sp. & 6 & - \\
\hline & Cerradomys sp. & 3 & - \\
\hline & Oecomys sp. & 6 & 2 \\
\hline & Oryzomys sp. & 2 & - \\
\hline \multicolumn{4}{|l|}{ Pantanal } \\
\hline Mato Grosso do & Clyomys laticeps & 8 & - \\
\hline \multirow[t]{2}{*}{ Sul } & Holochilus sp. & 6 & - \\
\hline & Thrichomy fosteri & 18 & 4 \\
\hline Total & & 457 & $100(21.88 \%)$ \\
\hline
\end{tabular}

only in Caatinga vs Cerrado ( $p=0.005)$, Caatinga vs Amazon Forest $(p=0.027)$ and Caatinga vs Atlantic Forest $(p=0.003)$.

Unfortunately, all positive samples to 16S rRNA gene that were submitted to RNaseP gene PCR showed weak bands intensity which precluded sequencing these fragments.

\subsection{Phylogenetic analyses}

The Blastn analysis showed that amplified sequences shared percentage of identity ranging from 86 to $99 \%$ with other murine hemoplasmas ('Candidatus $M$ haemomuris subsp. musculi', 'Candidatus M. haemomuris subsp. ratti' [formerly M. haemomuris], $M$. cocoides and with other sequences detected in rodents from Brazil and Hungary deposited in Genbank (Table 2).

The ML phylogenetic analysis based on a fragment of $1500 \mathrm{pb}$ (after the alignment by Bioedit) of 16S rRNA gene of 24 positive randomly selected samples showed the presence of ten distinct clusters. All clusters were positioned within M. haemofelis group and showed a strong separation supported by high bootstrap values (ranging from 97 to 100). The 16S rRNA hemoplasma sequences amplified from sylvatic rodents spleen samples clustered in eight different groups (clusters 1, 2, 3, 4, 5, 6, 8 and 10) (Fig. 2).

The cluster 1 consisted of five sequences that were obtained from three different rodent species (Akodon sp. [two sequences], Delomys dorsalis [one sequence], and Necromys lasiurus. [one sequence] sampled in Atlantic Forest, and $N$. lasiurus [one sequence] sampled in Cerrado biome). Two sequences, amplified from Thrichomys laurentius and Rhipidomys macrurus sampled in Caatinga biome, were positioned in the cluster 2 . The three sequences comprising the cluster 3 were amplified from rodents belonging to Oligoryzomys nigripes species captured in Atlantic Forest. The cluster 4 consisted of only one sequence amplified from Rhipidomys sp. captured in the Cerrado. Three sequences were grouped in cluster 5 (one detected in Nectomys rattus, one in Nectomys sp. and another in $N$. lasiurus species, which were sampled in Cerrado). The cluster 6 consisted on only one sequence, which was detected in Thrichomys fosteri in Pantanal biome. The cluster 8 consisted on two sequences obtained from Akodon sp. and $N$. lasiurus, which were captured in the Atlantic Forest. The cluster 10 consisted of only one sequence detected in Akodon sp. captured in the Atlantic Forest, closely related to Mycoplasma sp. detected in capybaras from Brazil. The percentage of identities (Blastn) between sequences obtained in the present study and other previously described is showed in Table 2.

Among the six synantropic rodents ( $R$. rattus captured in Amazon Forest and Cerrado) sequences, one (Cluster 7) was closely related to 'Candidatus $M$. haemomuris subsp. ratti' detected in $R$. rattus from Japan (AB758435), showing 99\% identity by Blast analysis. The five other sequences (Cluster 9) were closely related to Mycoplasma sp. detected in R. norvegicus from Japan (AB752303) and Hungary (KJ739312), both showing 99\% identity by Blast analysis.

\section{Discussion}

Several studies have suggested that hemotropic mycoplasmas have co-evolved with many animal species, including humans. The development of molecular assays primarily targeting the 16S rRNA gene has resulted in an increased number of recognitions of these pathogens in both animals and humans [14,34-36].

Herein we related an occurrence of $21.9 \%$ for hemoplasmas infecting sylvatic rodents from five different Brazilian biomes, as well as the phylogenetic assessment of hemoplasma genotypes circulating in wild rodents from Brazil. In Japan, 11.1\% (1/9) of synanthropic rodents sampled were positive to Mycoplasma

Table 2

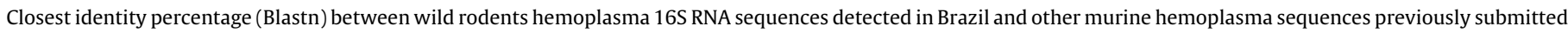
to GenBank from others regions of the world.

\begin{tabular}{|c|c|c|c|c|c|c|c|}
\hline & $\begin{array}{l}\text { 'C M. haemomuris } \\
\text { subsp. ratti’ } \\
(\mathrm{AB} 758435)\end{array}$ & $\begin{array}{l}\text { 'C M. haemomuris } \\
\text { subsp. musculi’ } \\
\text { (AB918692) }\end{array}$ & $\begin{array}{l}\text { Mycoplasma } \\
\text { cocoides } \\
\text { (AY171918) }\end{array}$ & $\begin{array}{l}\text { Mycoplasma sp. } \\
\text { (Micromys min) } \\
\text { (KC863983) }\end{array}$ & $\begin{array}{l}\text { Mycoplasma sp. } \\
\text { (R. norvegicus) } \\
\text { (AB752303) }\end{array}$ & $\begin{array}{l}\text { Mycoplasma sp. } \\
\text { (Hydrochaeris } \\
\text { hydrochaeris) (FJ667773) }\end{array}$ & $\begin{array}{l}\text { Mycoplasma sp. } \\
\text { (H. hydrochaeris) } \\
\text { (FJ667774) }\end{array}$ \\
\hline Cluster 1 & 93 & 93 & 91 & 90 & 90 & 89 & 89 \\
\hline KT215625 & 89 & 89 & 86 & 86 & 85 & 86 & 86 \\
\hline KT215626 & 93 & 93 & 90 & 90 & 89 & 89 & 89 \\
\hline Cluster 3 & 93 & 93 & 90 & 90 & 90 & 88 & 89 \\
\hline Cluster 4 & 93 & 93 & 89 & 90 & 89 & 88 & 89 \\
\hline Cluster 5 & 92 & 92 & 89 & 89 & 90 & 87 & 87 \\
\hline Cluster 6 & 93 & 93 & 89 & 89 & 89 & 88 & 88 \\
\hline Cluster 7 & 99 & 99 & 89 & 89 & 90 & 88 & 88 \\
\hline Cluster 8 & 90 & 89 & 90 & 89 & 93 & 88 & 89 \\
\hline Cluster 9 & 90 & 89 & 90 & 89 & 99 & 87 & 87 \\
\hline Cluster 10 & 91 & 89 & 93 & 96 & 89 & 92 & 92 \\
\hline
\end{tabular}

\footnotetext{
* The sequences highlighted belong to cluster 2 .
} 


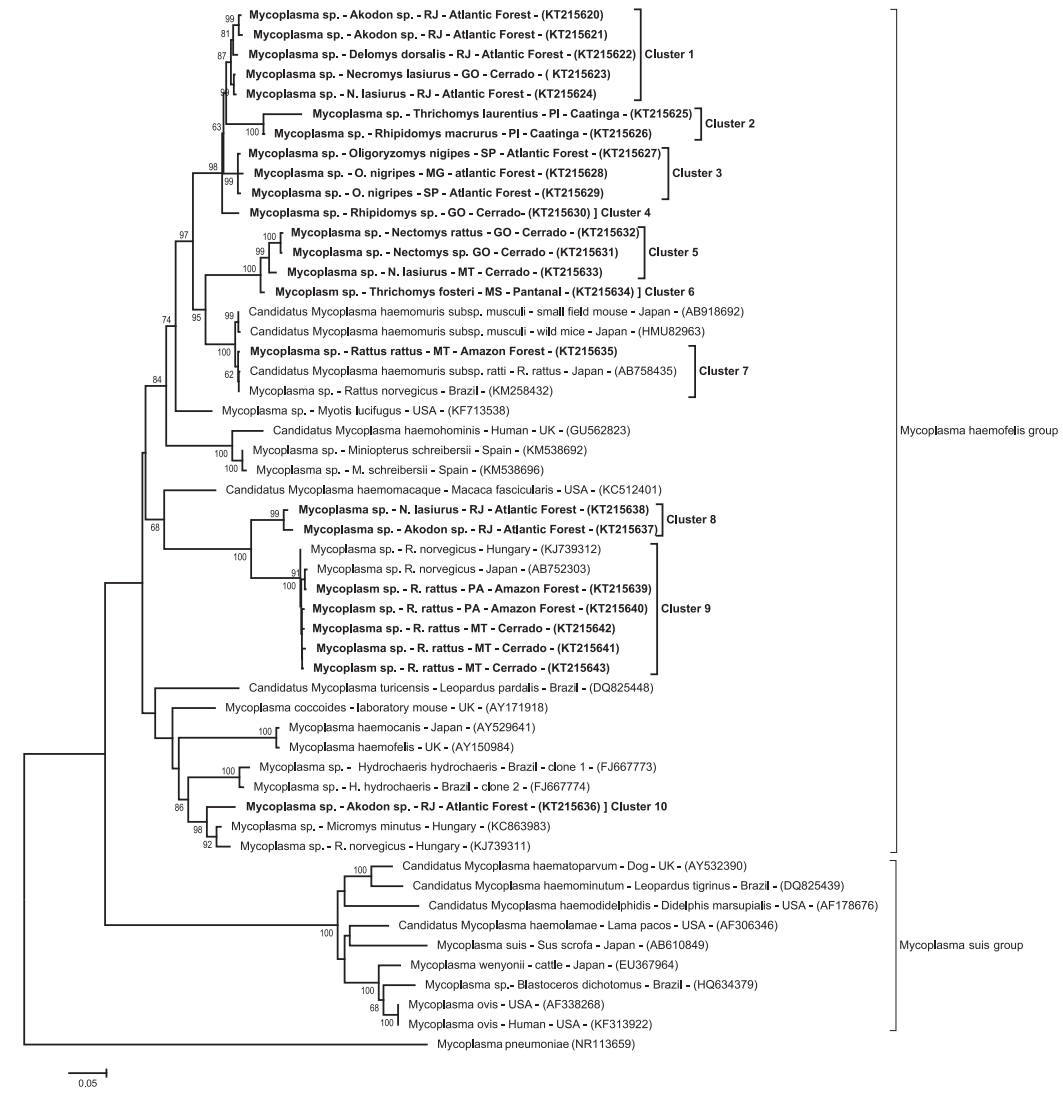

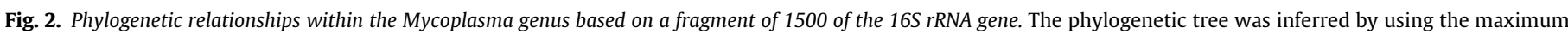

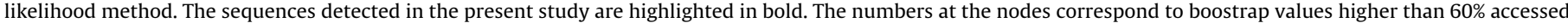
with 1000 replicates. Mycoplasma pneumoniae was used as outgroup.

spp., although the low number of animals analyzed might have influenced the overall prevalence of hemoplasmas [37]. Recently, Mycoplasma spp. were detected in 67.3\%(35/52) of rodents sampled in Hungary [14]. The smaller area where rodents were sampled in Hungary [14] - highlighting the aggregated distribution of parasitic diseases - compared to our study where rodents were sampled in five different biomes could explain the difference observed in the occurrence of hemoplasmas infecting wild rodents. Interesting, we observed statistical difference in the occurrence of Mycoplasma spp. between different biomes. Since hemoplasmas are vector-transmitted pathogens, we speculate that the distribution and abundance of arthropods may influence the occurrence of hemotropic mycoplasmas. Environmental factors, such as temperature, relative humidity, and seasonality may also have influence the Mycoplasma spp. occurrence. The Caatinga biome has a semiarid climate, characterized by very low humidity, low rainfall and high temperatures with long dry seasons, when compared with other Brazilian biomes [38]. These factors may affect the development of arthropods stages and decrease tyhe diversity and the abundance of vectors, which could explain the lower occurrence of Mycoplasma spp. in rodents from this biome. However, new studies are needed to access the gaps in biology of hemoplasmas. In Brazil, little is known about the occurrence and genetic diversity of hemoplasmas infecting wild animals. The first report of hemoplasma infecting rodents (Hydrochaeris hydrochaeris) in Brazil showed a higher occurrence $(64 \% ; 20 / 31)$ than that found in present study. The 16S rRNA sequences phylogenetic analyzesindicated divergence to other hemoplasma species previously detected in rodents [18].

The absence of a huge identity (85-96\%) between the sequences amplified from sylvatic rodent spleen samples in the present study and those retrieved from Genbank database (Table 2) highlights the existence of a high degree of genetic diversity among hemotropic mycoplasmas infecting wild rodents in Brazil. Overall, the phylogenetic analysis based on 16S rRNA sequences obtained in the present study showed the presence of ten distinct clusters, suggesting the possibility of novel hemoplasma infecting rodents in Brazil.

Although a recent study have suggested that the two distinct subgroups of $M$. haemomuris depended on species differences between the natural hosts of these strains rather than the geographic location of strain collections [15], we noticed that the majority of clusters obtained in the present study consisted on hemoplasma sequences amplified from rodents sampled in a specific biome, except for clusters 1 and 9. Besides, it is important to emphasize that there is a huge overlap of distribution areas of most of the rodent species found infected in the present study [10] and, consequently, a given genotype may circulate in different rodent species coexisting in a certain biome.

Interestingly, hemotropic mycoplasma detected in sylvatic rodents in the present study were phylogenetically distant from others murine hemoplasmas ( $M$. cocoides, 'Candidatus M. haemomuris subsp. musculi' and 'Candidatus $M$. haemomuris subsp. ratti'). Considering the fact that synanthropic rodents ( $R$. rattus, $R$. norvegicus and $M$. musculus) have an Asiatic origin and were introduced in Brazil only about 500yrs ago, we raise a hypothesis that the above mentioned hemotropic mycoplasma species were introduced together with synanthropic rodents during the European colonization. Additionally, our preliminary results suggest that these hemoplasmas species are restrict to synanthropic rodents or, at least, show a low occurrence among sylvatic rodents in Brazil. This hypothesis may have supported on the biology of synanthropic rodents in the environment. Although $R$. rattus and 
M. musculus have been reported in all Brazilian states, they are usually found closely to human habitation [10]. On the other hand, the natural environment in which sylvatic rodents are found comprises woods, forest, gallery forests, veredas and other less disturbed areas [10]. This fact might have reduced the contact and exchange of pathogens through arthropod vectors between synanthropic and sylvatic rodents, which consequently generate a low occurrence of these three hemoplasma species among sylvatic rodents. In addition, all DNA sequences detected in $R$. rattus in the present study were grouped with other Mycoplasma spp. previously detected in synanthropic rodents (clusters 7 and 9). However, future studies sampling a large number of synanthropic rodents are much needed to corroborate to this hypothesis.

Although studies have suggested that hemotropic mycoplasmas co-evolved with several animal species [14,34-36,], little is known about the origin, evolution and dispersion of hemoplasmas. According to our results, the Mycoplasma species detected in this present study already existed in Brazil circulating among the sylvatic rodents before introduction of synanthropic rodents and their respective hemoplasmas during the colonization. However, future studies using a phylogeographic approach, for example, are much needed to corroborate to this hypothesis.

Although the vector competence of $P$. serrata and $P$. spinulosa in transmitting murine hemoplasma ( $M$. coccoides) has been confirmed [17,39], the wide and complex diversity of hemotropic mycoplasmas infecting different rodent species revealed by our study associated to the fact that DNA of Mycoplasma spp. has been detected in fleas (Synosternus cleopatrae) collected from rodents (Gerbillus andersoni) [40], highlights the need of future studies to assess the role of other arthropod vectors (fleas, ticks, mites, etc.) in transmission cycles of these pathogens among rodents and other animals.

\section{Conclusion}

The phylogenetic assessment based on 16S rRNA sequences supported by a relative low percentage of identity found by Blast analysis suggest the circulation of novel hemoplasma species in rodents from different biomes in Brazil.

\section{Acknowledgments}

We are thankful to Dr. Paulo Sérgio D'Andrea and staff of Laboratory of Biology and Parasitology of Wild Mammals Reservoirs (FIOCRUZ, Rio de Janeiro, RJ), and Dr. Elba Regina Sampaio de Lemos (Laboratory of Hantavirosis and Rickettsiosis, FIOCRUZ, Rio de Janeiro, RJ).

\section{References}

[1] J.E. Foley, S. Harrus, A. Poland, B.B. Chomel, N.C. Pedersen, Molecular, clinical, and pathologic comparison of two distinct strains of Haemobartonella felis in domestic cats, Am. J. Vet. Res. 59 (1998) 1581-1588.

[2] B. Willi, C. Filone, J.L. Catão-Dias, V. Cattori, M.L. Meli, A. Vargas, et al. Wordwide occurrence of feline hemoplasma infections in wild felid species, J. Clin. Microbiol. 45 (2007) 1159-1166.

[3] A.W. Biondo, A.P. dos Santos, A.M. Guimarães, R.F. Vieira, O. Vidotto, D.B. Macieira, et al., A review of the occurrence of hemoplasma (hemotrophic mycoplasma) in Brazil, Rev. Bras. Parasitol. Vet. 18 (2009) 1-7.

[4] H. Neimark, K.-E. Johansson, Y. Rikihisa, J.G. Tully, Proposal to transfer some members of the genera Haemobartonella and Eperythrozoon to the genus Mycoplasma with descriptions of 'Candidatus Mycoplasma haemofelis', 'Candidatus Mycoplasma haemomuris' 'Candidatus Mycoplasma haemosuis' and ‘Candidatus Mycoplasma wenyonii', Int. J. Syst. Evol. Microbiol. 51 (2001) 891-899.

[5] H. Neimark, P. Wallace, B.L. Robinson, L.B. Stewart, Phylogenetic analysis and description of Eperythrozoon coccoides, proposal to transfer to the genus Mycoplasma as Mycoplasma coccoides comb. nov. and Request for an Opinion, Int. J. Syst. Evol. Microbiol. 55 (2005) 1385-1391.
[6] S. Tasker, C.R. Helps, M.J. Day, D.A. Harbour, S.E. Shaw, S. Harrus, et al., Phylogenetic analysis of hemoplasma species: an international study, J. Clin. Microbiol. 41 (2003) 3877-3880.

[7] B. Willi, M.L. Meli, L. Ruedi, H. Honegger, N. Wengi, L.E. Hoelzle, et al., Development and application of a universal hemoplasma screening assay based on the SYBR Green PCR principle, J. Clin. Microbiol. 47 (2009) 4049-4054.

[8] R.G. Maggi, S.M. Compton, C.L. Trull, P.E. Mascarelli, B.R. Mozayeni, E.D. Breitschwerdt, Infection with hemotropic Mycoplasma species in patients with or without extensive arthropod or animals contact, J. Clin. Microbiol. 51 (2013) 3237-3241.

[9] J. Millán, M. López-Roig, V. Delicado, J. Serra-Cobo, F. Esperón, Widespread infection with hemotropic mycoplasmas in bats in Spain, including a hemoplasma closely related to "Candidatus Mycoplasma hemohominis", Comp. Immunol. Microbiol. Infect. Dis. 39 (2015) 9-12.

[10] C.R. Bonvicino, J.A. Oliveira, P.S. D’Andrea, Guia dos Roedores do Brasil com chaves para gêneros baseadas em caracteres externos, Centro Pan-Americano de Febre Aftosa-OPAS/OMS, Rio de Janeiro, 2008.

[11] S. Davis, E. Calvet, H. Leirs, Fluctuating rodent populations and risk to humans from rodent-borne zoonoses, Vector Borne Zoonotic Dis. 5 (2005) 305-314.

[12] B.G. Meerburg, G.R. Singleton, A. Kijlstra, Rodent-borne diseases and their risks for public health, Crit. Rev. Microbiol. 35 (2009) 221-270.

[13] A.L.R. Roque, A.M. Jasen, Wild and synanthropic reservoirs of Leishmania species in the Americas, Int. J. Parasitol. Parasites Wildl. 3 (2014) 251-262

[14] S. Hornok, G. Foldvári, K. Rigó, M.L. Meli, E. Gonczi, A. Répási, et al. Synantropic rodents and their ectoparasites as carriers of a novel haemoplasma and vector-borne, zoonotic pathogens indoors, Parasitol. Vectors 15 (2015) 8-27

[15] Y. Kaneko, N. Ishii, Apodemus argenteus The IUCN Red List of Threatened Species. Version 2015. 2, 2008, 〈www.iucnredlist.org〉 (downloaded on 20 June 2015)

[16] R. Harasawa, H. Fujita, T. Kadosaka, S. Ando, Y. Rikihisa, Proposal for 'Candidatus Mycoplasma haemomuris subsp. musculi' in mice, and ‘Candidatus Mycoplasma haemomuris subsp. ratti’ in rats, Int. J. Syst. Evol. Microbiol. 65 (2015) 734-736.

[17] S.D. Berkenkamp, R.B. Wescott, Arthropod transmission of Eperythrozoon coccoides in mice, Lab. Anim. Sci. 38 (1988) 398-401.

[18] R.F. Vieira, M.B. Molento, L.C. dos Santos, W. Moraes, Z.S. Cubas, A.P. Santos, A.M. Guimares, A. Mohamed, I.R. Barros Filho, A.W. Biondo, J.B. Messick, Detection of a novel hemoplasma based on 16S rRNA gene DNA in captive and free-ranging capybaras (Hydrochaeris hydrochaeris), Vet. Microbiol. 139 (2013) 410-413.

[19] M.R. André, C.H. Adania, S.M. Allegretti, R.Z. Machado, Hemoplasma in wild canids and felids in Brazil, J. Zool. Wildl. Med. 42 (2011) 342-347.

[20] A.L. Grazziotin, J.M.B. Duarte, M.P.J. Szabó, A.P. Santos, M.A.S. Gimarães, A. Mohamed, R.F. Vieira, I.R. Barros Filho, A.W. Biondo, J.B. Messick, Prevalence and molecular characterization of Mycoplasma ovis in selected free-ranging Brazilian deer populations, J. Wildl. Dis. 47 (2011) 1005-1011.

[21] L.C. Santos, M.P. Cubilla, W. de Moraes, Z.S. Cubas, M.J. Oliveira, M. Estrada, C.M. Leutenegger, J.E. Sykes, L.L. Lindsay, M. Marcondes, I.R. Barros Filho, A.W. Biondo, Hemotropic mycoplasma in free-ranging Black howler monkey (Alouatta caraya) in Brazil, J. Wildl. Dis. 49 (2013) 728-731.

[22] L. Bonato, M.A.P. Figueiredo, L.R. Gonçalves, R.Z. Machado, M.R. André, Occurrence and molecular characterization of Bartonella spp. and hemoplasmas in neotropical primates from Brazilian Amazon, Comp. Immunol. Microbiol. Infect. Dis. 42 (2015) 15-20.

[23] H.M. Herrera, A. Norek, T.P.T. Freitas, V. Rademaker, O. Fernandes, A.M Jansem, Domestic and wild mammals infection by Trypanosoma evansi in a pristine area of the Brazilian Pantanal region, Parasitol. Res. 96 (2005) 121-126.

[24] V. Rademaker, H.M. Herrera, T.R. Raffel, P.S. D’Andrea, T.P.T. Freitas, U.G. Abreu, et al., What is the role of small rodents in the transmission cycle of Trypanosoma cruzi and Trypanosoma evansi (Kinetoplastida Trypanosomatidae)? A study case in the Brazilian Pantanal, Acta Trop. 111 (2009) 102-107

[25] R. Cássia-Pires, M.C. Boité, P.S. D’Andrea, H.M. Herrera, E. Cupolillo, A.M. Jansem, et al., Distinct Leishmania species infecting wild caviomorph rodents (Rodentia: Hystricognathi) from Brazil, PLoS Negl. Trop. Dis. 8 (2014) e3389, http://dx.doi.org/10.1371/journal.pntd.0003389.

[26] E.C. Ferreira, C.M. Gontijo, I. Cruz, M.N. Melo, A.M. Silva, P.C.R. Alternative, protocol using a single primer set for assessing DNA quality in several tissues from a large variety of mammalian species living in areas endemic for leishmaniasis, Mem. Inst. Oswaldo Cruz 105 (2010) 895-898.

[27] A.J. Birkenheuer, M.G. Levy, E.B. Breitschwerdt, Development and evaluation of a seminested PCR for detection and differentiation of Babesia gibsoni (Asian genotype) and B. canis DNA in canine blood samples, J. Clin. Microbiol. 41 (2013) 4172-4177

[28] N.G. Miceli, F.A. Gaviole, L.R. Gonçalves, M.R. André, V.R. Sousa, K.C. Sousa, et al., Molecular detection of feline arthropod-borne pathogens in cats in Cuiabá, state of Mato Grosso, central-western region of Brazil, Rev. Bras. Parasitol. Vet. 23 (2013) 385-390.

[29] S.F. Altschul, W. Gish, W. Miller, E.W. Myers, D.J. Lipman, Basic local alignment search tool, J. Mol. Biol. 215 (1990) 403-410. 
[30] J.D. Thompson, D.G. Higgins, T.J. Gibson, W: CLUSTAL. Improving the sensitivity of progressive multiple sequence alignment through sequence weighting, position specific gap penalties and weight matrix choice, Acids Res. 22 (1994) 1673-4680.

[31] T.A. Hall, BioEdit: a user-friendly biological sequence alignment editor and analysis program for Windows 95/98/NT, Nucl. Acids Symp. Ser. 41 (1999) 95-98.

[32] A. Stamatakis, P. Hoover, J. Rougemont, A rapid bootstrap algorithm for the RAxML Web servers, Syst. Biol. 57 (2008) 758-771.

[33] M.A. Miller, W. Pfeiffer, T. Schwartz, CIPRES. Creating the, Creating the CIPRES science gateway for inference of large phylogenetic trees, in: Proceedings of the Gateway Computing Environments Workshop (GCE), New Orleans, LA, 2010, pp. 1-8.

[34] A.P. dos Santos, R.P. dos Santos, A.W. Biondo, J.M. Dora, L.Z. Goldani, S.T. de Oliveira, et al., Hemoplasma infection in HIV-positive patient, Braz. Emerg. Infect. Dis. 14 (2008) 1922-1924.
[35] J.E. Sykes, Feline hemotropic mycoplasmas, J. Vet. Emerg. Crit. Care 20 (2010) 62-69.

[36] R.G. Maggi, M.C. Chitwood, S. Kennedy-Stoskopf, C.S. DePerno, Novel hemotropic Mycoplasma species in white-tailed deer (Odocoileus virginianus), Comp. Immunol. Microbiol. Infect. Dis. 36 (2013) 607-611.

[37] H. Sashida, F. Sasaoka, J. Suzuki, Y. Watanabe, M. Fujihara, K. Nagai, S. Kobayashi, K. Furuhama, R. Harasawa, Detection of hemotropic Mycoplasmas in free-linving brown sewer rats (Rattus norvegicus), J. Vet. Med. Sci. 75 (2013) 979-983.

[38] F. Mendonça, I.M. Danni-Oliveira, Climatologia: Noções básicas e climas do Brasil São Paulo: Oficina de Textos. 2007. Soc. Nat. 22 (2010) 639-640.

[39] C.P. Eliot, The insect vector for the natural transmission Eperythrozoon coccoides in mice, Science 84 (1936) 397.

[40] C. Cohen, E. Toh, D. Munro, Q. Dong, H. Hawlena, Similarities and seasonal variations in bacterial communities from the blood of rodents and from their flea vectors, ISME J. 9 (2015) 1662-1676. 